\title{
Comparison of Islamic Banks with Conventional Banks: Evidence from an Emerging Market
}

\author{
Ameenullah Aman* Saqib Sharif ${ }^{\dagger} \quad$ Imtiaz Arif $^{\ddagger}$
}

\begin{abstract}
This paper evaluates and compares the performance of Sharia-compliant banks with their conventional counterparts operating in Pakistan. Data of five completely Islamic Banks(IBs) and fifteen Conventional Banks (CBs), from Pakistan, have been used for the study. Study period comprises of six years from year 2008 to year 2013. Bank's orientation, efficiency, quality of assets and stability are the measures used to compare the performance of Shariah-compliant and conventional banks. The Islamic Banks in Pakistan are younger in age and smaller in size compared to the Conventional Banks. Based on the financial ratios of two types of banks, we find that the business model of Islamic Banks is inferior to the model of Conventional Banks. Islamic Banks are less cost efficient than Conventional Banks. However, Islamic Banks have superior asset quality with better bank stability position.
\end{abstract}

Keywords: Islamic banking, state bank of Pakistan, business model, efficiency, asset quality, stability.

\section{Introduction}

In the last couple of decades, Islamic Banks (IBs) have grown in size and number in Pakistan. Competition between two different banking systems, Islamic and conventional, has intensified over the past decade. The market share of IBs assets and deposits in overall banking industry of Pakistan has reached to $9.4 \%$ and $10.7 \%$ respectively (Islamic Banking Bulletin March 2014 - The Central Bank, 2014). Major financial institutions of the country are strategically entering into these new markets and are offering diverse spectrum of products and services to consolidate their presence and boost their profitability. The differentiation between IBs and Conventional Banks $(\mathrm{CBs})$ is drawn from a regulatory aspect. IBs follow Sharia principles and offer Shariah-compliant financing or banking in contrast to their counterparts. Shariah-compliant banking prohibit interest on debt in any form, proscribe gharar, to discourage excessive uncertainty in contracts, enhance disclosure, and prevent all forms of deception. It eliminates pure debt securities from the financial system, and replaces it with the rate of return earned ex-post on contracts of exchange or risk sharing. It also calls for bank deposits to be collected on a profit/loss (PLS) sharing basis rather than fixed predetermined liabilities. It promotes financing of trade, exchange of goods and services, and ensures that all financial contracts are backed by assets or transactions/activities in the real economic sector as well as have distinctive risk profiles (Mohieldin, 2012).

\footnotetext{
*Lecturer, Department of Management Sciences, IQRA University. E-mail: ameenullah.shaikh@iuk.edu.pk

${ }^{\dagger}$ Assistant Professor, Department of Economics and Finance, Institute of Business Administration. E-mail: ssharif@iba.edu.pk

¥Assistant Professor, Department of Management Scienses, IQRA University. E-mail: arif.i@iuk.edu.pk
} 
IBs operate alongside CBs and form a parallel market for Shariah-compliant financial products and services. Businesses and households within the economy have the option to either avail the services provided by conventional or Islamic banking channel. The world's financial crisis in 2008, and superior performance of IBs during the crisis have made people skeptical about the satisfactory functioning of typical "Conventional" banking system (Hasan \& Dridi, 2011). This situation benefited Islamic banking system with the increase in market share and a tremendous growth in assets and overall size of the banks.

The steady growth in the size and increase in the number of IBs determines that people have started taking this banking system as an alternative to the conventional system. This situation establishes the need of investigation of IBs operations and study of the comparative outlook of Islamic and conventional banks. This would provide investors and other stakeholders of banks a potential understanding of differentiation between the two banking paradigms in terms of risks and rewards attached to them.

Hence, this study investigates the competitiveness of Islamic and conventional banking in Pakistan. The orientation of business model of IBs and CBs is entirely different as former is based on financing principles and the latter works out its operations on the principles of lending. This creates unique avenues of risks and rewards to both the banking systems. Therefore, this study contributes to the prevalent literature on Islamic banking and finance with the comparative business outlook of CBs.

The rest of the paper is organized as follows: In the next section, the literature review relating to comparison of two parallel banking systems. Next, we present the methodology that describes the sample, data collection technique, and the measurements of the stimulus. The section on results presents the data analysis and the findings followed by the discussion and implication section where the findings are expounded.

\section{Literature Review}

Theoretically we have no support to predict whether IBs are more cost-effective or more stable than CBs (Beck, Demirgüç-Kunt, \& Merrouche, 2013). The equity-like nature of the saving and investment deposits may give more control to depositors' to screen and discipline the bank at the same time it allows loose control of banks on borrowers since the threat of immediate withdraw from depositors dissipate, which increase the overall riskiness of the asset. Moreover, Sharia principles, in order to have all transactions backed by real economic transactions that involves tangible assets limit the use of hedging instruments for banks. In the same way, considerable indefiniteness relates to the efficiency of IBs. On the one hand, monitoring and screening costs might be lower for IBs on the other hand, the higher complexities of IBs might result in higher costs and thus lower efficiency of IBs (Rosly \& Bakar, 2003; Samad \& Hassan, 1999). Further, the younger age of IBs as compared to most conventional banks might imply higher cost structures. However, Erol, Baklaci, Aydoğan, and Tunç (2014) found that IBs in Turkey out-performed CBs in earnings, asset quality, and liquidity ratios. Similarly, Rosly and Bakar (2003) also found that IBs have higher Return on Asset (ROA) and profit margins. On the contrary, in a comparative study using different financial ratios Samad (2004); Hassan, Mohamad, and Khaled I. Bader (2009) reported, that despite having significantly higher volume of deposits there was no distinct difference in profitability (ROA, ROE),efficiency and revenue of both types of banks. However, availability of more liquidity in Islamic banks make them less prone to liquidity risk and credit risk as compared to their counterparts.

To examine the performance of a bank we need to understand the set of internal and external 
banking characteristics. Since the ultimate objective of management is to maximize the value of shareholder's equity, an optimal mix of returns and risk exposure should be pursued in order to increase the profitability of the bank. Hence, a comprehensive plan to identify objectives, goals, budgets, and strategies should be developed by the bank management. The planning should encompass both internal and external performance dimensions. Increasing innovations and deregulation in the financial services industry are leading to, internal and external competitiveness is becoming a critical factor in evaluating performance. While internal performance is evaluated by analyzing financial ratios, external performance is best measured by evaluating the bank's market share, and public confidence (Bashir et al., 2003)

Therefore, to achieve the objectives of this study we used measures of business model, cost efficiency, asset quality and stability to compare the bank specific performance of the two banking systems using Beck et al. (2013) methodology.

\section{Business Model}

Business model of a bank determines the major sources of fund a bank is relying on and how these funds are being utilised. To study this, three different ratios are used as discussed in (Beck et al., 2013). Non-Markup Income to Total Income (NMI), which tells about the dependency of a bank on income other than markup such as fee and service income. Non-Deposit Funding to Total Funding (NDF) is used to observe the nature of sources of funding in a bank, it is used to identify the portion of equity and institutional funding. Loan to deposit ratio ( $L D R)$ is used, as a measure to know the ability of a bank for placement of funds out of total deposits.

\section{Efficiency}

Efficiency level of a bank determines the competency of a bank in maintaining its costs at minimal levels (Hassan et al., 2009). To study this, two different ratios are used as discussed in Beck et al. (2013). Cost to income ratio (CIR) is used, which states about a portion of income a bank is deploying in paying its cost. To see the economic efficiency of any entity, Cost-Income ratio (CIR) is among the best indexes to be used (Samad, 2004). Total operating cost to total assets (TOC) is used to see particularly the operational efficiency of a bank.

\section{Asset Quality}

Asset quality of a bank determines that how bank is performing in advances and placements. To study this, two different ratios are used as discussed in Beck, Demirgüç-Kunt, and Levine (2006); Beck et al. (2013). Loan Loss Reserve (LLR) is used, which tells about the ability of successfully maintaining enough reserve pool for possible defaults in assets. Non-performing loans to Total loans (NPL) is used to see the bank's rate of default on loans and advances.

\section{Stability}

Stability of a bank determines the solvency position of a bank. Using a classic Merton Credit Risk framework Farooq, Van Wijnbergen, and Zaheer (2015); Abedifar, Molyneux, and Tarazi (2013); Zaheer, Ongena, and Van Wijnbergen (2013) showed that IBs can be expected to take lower risks in comparison to their CBs counterparts, IBs have less incentive for risk shifting, both in and outside of distress situations. Therefore, such banks are expected to be more stable and have better quality. 
To study this, four different ratios are used as discussed in Beck et al. (2013). Liquid assets to Total deposits (Maturity Match)(LDA) tells about the liquidity position of a bank. Zscore is used to evaluate the solvency level of a bank. Return on assets (ROA) is used to analyze the profitability and Equity to Asset Ratio (EAR) is used to explore the capital structuring of a bank.

\section{Data}

We obtained data from the State Bank of Pakistan to construct and compare financial ratios of Islamic and conventional banks of Pakistan. Our sample period is from 2008 to 2013 for twenty banks that consists of five completely IBs and fifteen CBs.

\section{Analysis and Results}

Table 1 presents descriptive statistics and univariate comparisons of two parallel bank types. Specifically, mean, standard deviation, minimum and maximum as well as average value for conventional and Islamic banks for each variable as well as the p-value of a two-sided t-test are presented.

Firstly, we compared the business orientation of conventional and Islamic banks, using two indicators suggested by Demirgüç-Kunt and Huizinga (2010) as well as the traditional loan-deposit ratio. Specifically, we explored the extent to which Islamic and conventional banks are involved in fee-based business by using the ratio of non-markup income to total income (NMI). In our sample, the share of fee-based income to total income varies from $0.77 \%$ to $36.62 \%$, with an average of $12.52 \%$. We also consider the importance of non-deposit funding to total funding (NDF), which ranges from zero to $45.54 \%$ in our sample, with an average of $10.07 \%$. The loan to deposit ratio ( $L D R$ ) varies from $33.71 \%$ to $111.5 \%$, with a mean of $65.97 \%$. IBs in Pakistan have significantly less NMI (10.490 vs 13.199), lower NDF (4.710 vs 11.853 ) and LDR (58.178 vs 68.568 ) than CBs, these finding defy the findings of Beck et al. (2013). The univariate contrast suggests that IBs are self-sufficient in financing their core business through their deposit base from traditional investment accounts. Yet, at the same time, they have fewer avenues to utilize the available funds. Therefore, loan to deposit ratio is less than their conventional counterparts.

Secondly, the efficiency levels of both banking systems are analyzed. The operating costs to total assets (TOC) of banks vary from $0.5 \%$ to $8.86 \%$ with an average of $3.182 \%$. IBs have significantly higher operating costs with an average of $43.54 \%$ than CBs with an average of $29.58 \%$. Further the cost-income ratio (CIR) of all banks ranges from $6.74 \%$ to $82.18 \%$ with an average of $33.09 \%$. Again, the IBs have higher cost-income pattern than CBs. It may be due to the young age of IBs in Pakistan.

Thirdly, to analyze the asset quality of both types of banks, we have taken two indicators. Loan Loss Reserve (LLR) and Non-Performing Loans (NPL), both are divided by total gross loans of a bank. Loan loss reserves to gross loans ranges from $0 \%$ to $28.39 \%$ with an average of $8.51 \%$, whereas the ratio of non-performing loans to gross loans ranges from $0.02 \%$ to $51.56 \%$ with an average of $13.03 \%$. IBs have significantly lower ratios of loan loss reserves and non-performing loans than CBs that suggest better asset quality.

Finally, to analyze bank stability, four indicators are obtained; i.e. ratio of liquid assets to total deposits to check maturity match, Zscore to measure stability, return on assets(ROA) to see profitability and ratio of bank equity to total assets (EAR) to check capitalization pattern. The ratio of liquid assets to total deposits of banks ranges from $4.47 \%$ to $35.13 \%$ with an average of $12.81 \%$. There is a significant difference between Islamic and conventional banks in maturity 
match as IBs are more liquid than conventional banks. Z-score ranges from -1.07 to 80.181 with an average of $23.08 \%$. IBs have lower Z-score which makes them closer to insolvency than conventional counterparts. This result is insignificant and inconsistent to Beck et al. (2013) study. Return on assets of banks varies from $-7.08 \%$ to $3.47 \%$ with an average of $0.13 \%$. The ratio of bank equity to total assets ranges from $-3.10 \%$ to $43.09 \%$ with an average of $11.45 \%$. IBs have lower profitability but better capitalization although these are on insignificant levels. Thus the results of bank stability suggest that there is no significant difference between Islamic and conventional banks as far as their stability is concerned.

Table 1

Descriptive Statistics and Univariate Comparisons

\begin{tabular}{|c|c|c|c|c|c|c|c|c|}
\hline Variable & Obs. & Mean & Std. Dev. & Minimum & Maximum & $\begin{array}{r}\text { Islamic } \\
\text { Banks }\end{array}$ & $\begin{array}{c}\text { Conventional } \\
\text { Banks }\end{array}$ & $\begin{array}{c}\text { Difference } \\
\text { t-test } \\
\text { p-values }\end{array}$ \\
\hline \multicolumn{9}{|l|}{ Business Model } \\
\hline NMI $(\%)$ & 120 & 12.522 & 5.501 & 0.770 & 36.620 & 10.490 & 13.199 & 0.019 \\
\hline NDF (\%) & 120 & 10.067 & 8.960 & 0.000 & 45.540 & 4.710 & 11.853 & 0.000 \\
\hline LDR $(\%)$ & 120 & 65.971 & 17.261 & 33.710 & 111.500 & 58.178 & 68.568 & 0.004 \\
\hline \multicolumn{9}{|l|}{ Efficiency } \\
\hline CIR (\%) & 119 & 33.098 & 14.733 & 6.740 & 82.180 & 3.896 & 2.944 & 0.000 \\
\hline TOC $(\%)$ & 120 & 3.182 & 1.308 & 0.500 & 8.860 & 43.542 & 29.578 & 0.000 \\
\hline \multicolumn{9}{|l|}{ Asset Quality } \\
\hline LLR (\%) & 120 & 8.513 & 6.321 & 0.000 & 28.390 & 3.811 & 10.081 & 0.000 \\
\hline NPL (\%) & 120 & 13.037 & 10.571 & 0.020 & 51.560 & 7.542 & 14.868 & 0.000 \\
\hline \multicolumn{9}{|l|}{ Stability } \\
\hline Maturity Match (\%) & 120 & 12.810 & 4.890 & 4.470 & 35.130 & 15.617 & 11.874 & 0.006 \\
\hline Zscore & 120 & 23.079 & 18.431 & -1.071 & 80.181 & 19.192 & 24.375 & 0.079 \\
\hline ROA (\%) & 120 & 0.130 & 1.990 & -7.080 & 3.470 & -0.199 & 0.239 & 0.298 \\
\hline EAR (\%) & 120 & 11.452 & 8.315 & -3.100 & 43.090 & 14.009 & 10.600 & 0.051 \\
\hline \multicolumn{9}{|l|}{ Control variables } \\
\hline LNTA (\%) & 120 & 18.732 & 1.360 & 15.800 & 21.260 & 17.785 & 19.048 & 0.000 \\
\hline NLA2TA (\%) & 120 & 46.161 & 10.332 & 19.480 & 68.850 & 47.778 & 45.622 & 0.324 \\
\hline FA2TA $(\%)$ & 120 & 3.356 & 1.995 & 0.870 & 11.540 & 3.916 & 3.169 & 0.076 \\
\hline $\mathrm{AGE}$ & 120 & 18.192 & 12.169 & 2.000 & 39.000 & 7.100 & 21.889 & 0.000 \\
\hline
\end{tabular}

Source: Authors' Esitmation

While univariate comparisons show significant differences between Islamic and conventional banks, these differences could be driven by other bank characteristics. To assess differences in business model, efficiency, asset quality, and stability between two bank types, we therefore run the following regression:

$$
B_{i, t}=\alpha+\beta X_{i, t}+\delta I_{i}+\eta_{i, t}
$$

Where, $B$ is one of our measures of business model, efficiency, asset quality and stability of bank $i$ in year $t, X$ is a vector of time-varying bank characteristics, $I$ is a dummy variable taking the value 1 for Islamic banks and $\eta$ is an error term.

The results in Table 2 show regression equation parameters of all eleven variables taken into consideration for comparing IBs and CBs without controlling for time varying bank characteristics. 


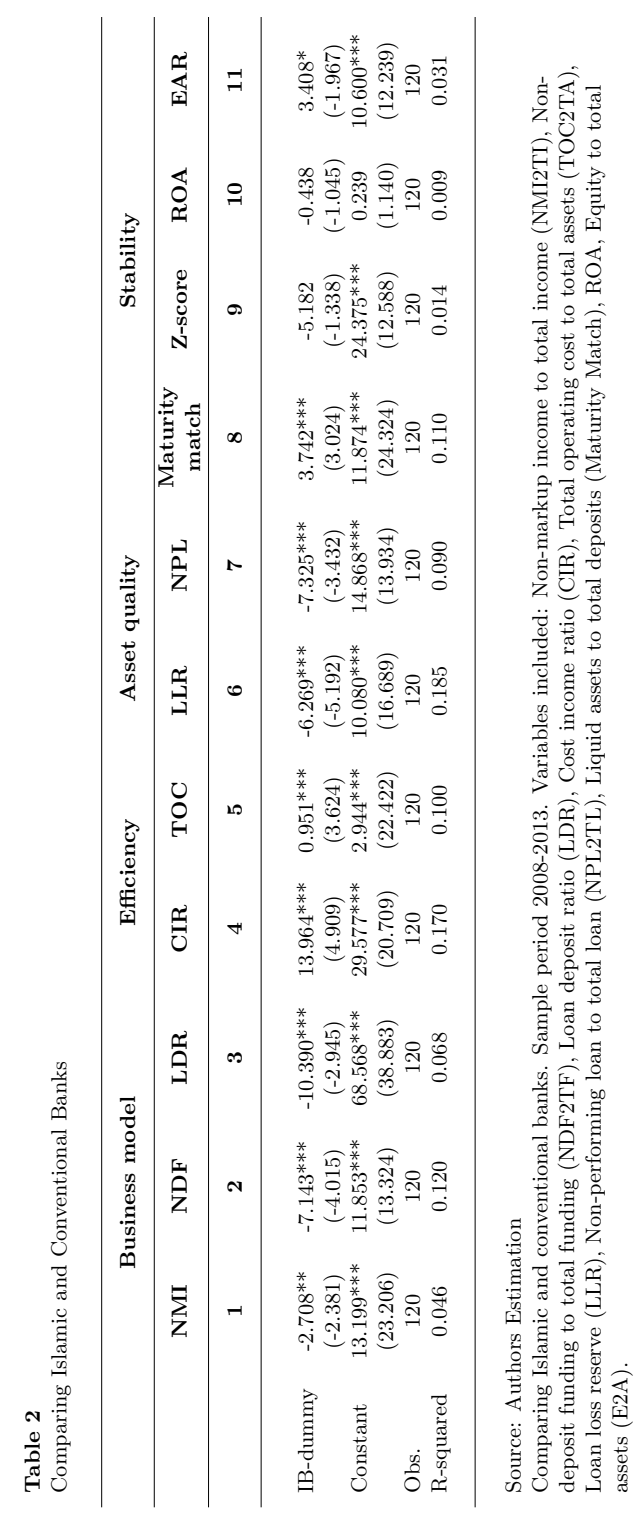

Analysis of the results shows that IBs have a significant level of higher cost-income ratio and higher overhead costs with p-values $<0.01$ for each. This result is consistent with (Beck et al., 2013). This also suggests that IBs are less cost efficient than their conventional counterparts.

Alternatively, IBs have significantly lower non-performing loans and higher capital-asset ratio with strong significance than CBs in Pakistan. This result is also consistent with Beck et al. (2013); Rosly and Bakar (2003). This signifies IBs with better asset quality and in better stability position due to superior capitalization structure than CBs in Pakistan. 


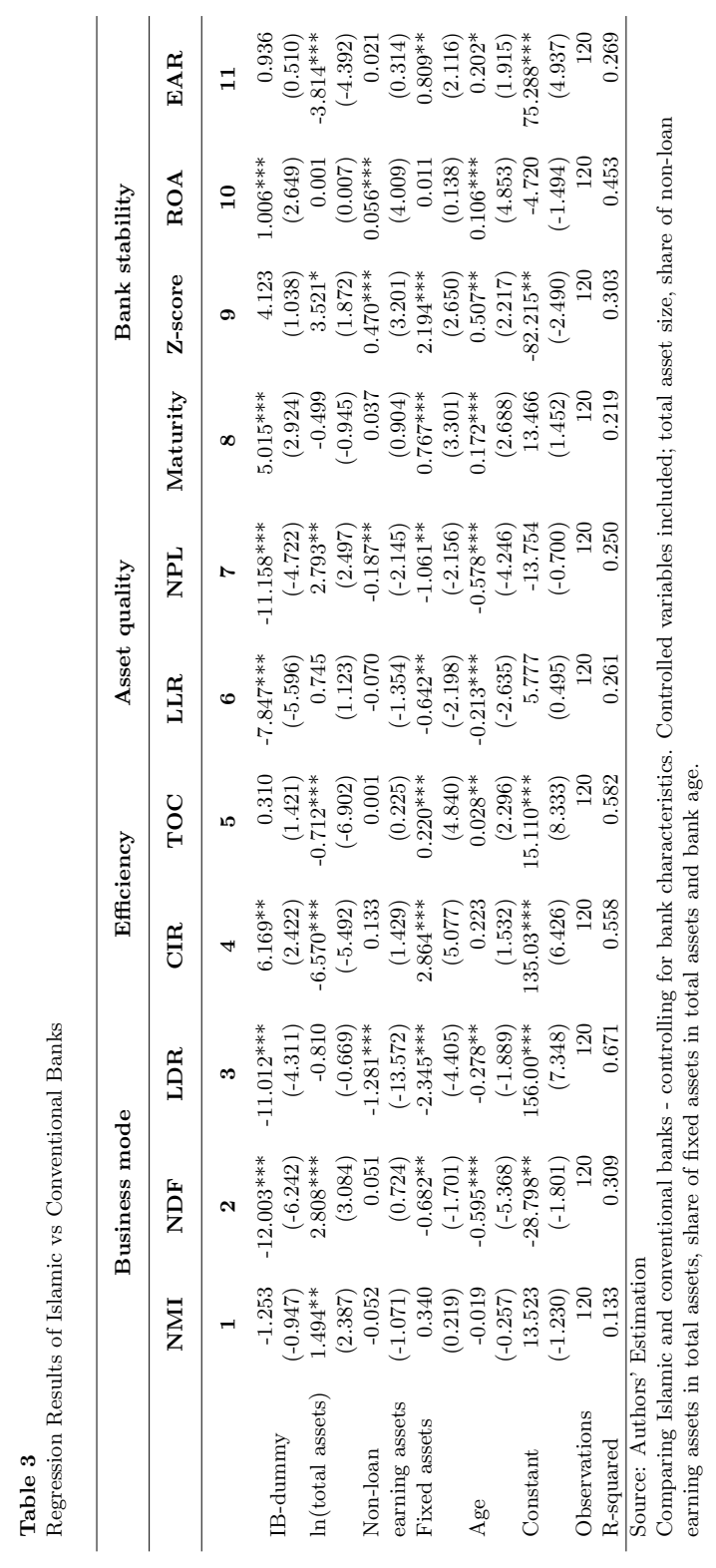


However, results of business model of Islamic and conventional banks in table 2 shows that IBs have significantly lower loan deposit ratio with $p-$ value $<0.01$. This determines the inferior business model of IBs as compared to CBs. Although these results are inconsistent with the previous study of Beck et al. (2013), this is mainly because IBs are restricted to only those investment avenues which are found compliant with Islamic principles and this restriction is strictly observed in Pakistan due to prevalent strong regulatory framework for compliance of Islamic principles on bank (Ali \& Raza, 2015) as well as at the central bank level therefore IBs find comparatively less opportunities of advancement than CBs.

Table 3 shows the results of comparison of IBs with conventional counterparts while controlling specific effects of bank size, age and nature of assets by introducing log of total assets, the ratio of non-loan earning assets and fixed assets in total assets and bank age. Here we find consistency between coefficients of both Tables 2 and Table 3 with significantly lower loan-deposit ratio and higher cost-income ratio and insignificantly higher overhead costs and higher capitalization of IBs than CBs. It confirms that IBs have lower efficiency in intermediation and cost but at the same time they have insignificantly superior capitalization than CBs.

Moreover, control variables introduced in Table 3 determine that larger banks have higher loan deposit and cost-income ratios, higher overhead costs, more liquidity and higher profitability and capitalization ratios. Banks with more non-loan earning assets to total assets have lower loan-deposit ratio but higher cost-income ratio, higher overhead costs and more non-performing loans. Also banks with higher fixed assets rely more on deposit funding with lesser loan deposit ratio and overhead costs. Finally the banks with more age have significantly lower cost income ratio and overheads.

\section{Conclusion}

Islamic banking is appearing as a growing and emerging business globally as well as locally in Pakistan, with an independent existence in overall banking industry. Central bank of Pakistan is issuing new commercial banking licenses to IBs only. Conversion of few existing CBs with significant branch network to full-fledged Islamic banking business has also been observed in the country. Keeping this scenario in observation, this paper compares two prevailing banking systems, Islamic and conventional, of the country. The study provides variety of comparisons which include orientation of two banking systems i.e. bank business model, operational difference i.e. efficiency, asset quality and bank stability position.

This study finds that IBs are comparatively under-performing on the basis of their business model and operational efficiency levels although they have better asset quality and superior stability position than CBs. IBs always have comparatively less credit placement opportunities than CBs because of avoidance of investment avenues which are repugnant to Islamic principles, therefore IBs find excess liquidity issues which lead bank to inferior business model but meanwhile this situation benefits IBs in terms of less non-performing assets thus they have better asset quality. Moreover, IBs due to younger age with little market share do not enjoy the benefits of economies of scale hence they have higher administrative charges and are relatively inefficient than CBs. The capital structure of IBs comprises significant portion of equity participation with comparatively higher equity to asset ratio that renders this banking business with superior stability position than conventional counterparts. 


\section{References}

Abedifar, P., Molyneux, P., \& Tarazi, A. (2013). Risk in islamic banking. Review of Finance, 17(6), 2035-2096.

Ali, M., \& Raza, S. A. (2015). Service quality perception and customer satisfaction in Islamic banks of Pakistan: the modified SERVQUAL model. Total Quality Management \& Business Excellence, 1-19. doi: 10.1080/14783363.2015.1100517

Bashir, A.-H. M., et al. (2003). Determinants of profitability in islamic banks: Some evidence from the middle east. Islamic Economic Studies, 11(1), 31-57.

Beck, T., Demirgüç-Kunt, A., \& Levine, R. (2006). Bank concentration, competition, and crises: First results. Journal of Banking \& Finance, 30 (5), 1581-1603.

Beck, T., Demirgüç-Kunt, A., \& Merrouche, O. (2013). Islamic vs. conventional banking: Business model, efficiency and stability. Journal of Banking \& Finance, 37(2), 433447.

Demirgüç-Kunt, A., \& Huizinga, H. (2010). Bank activity and funding strategies: The impact on risk and returns. Journal of Financial Economics, 98(3), 626-650.

Erol, C., Baklaci, H., Aydoğan, B., \& Tunç, G. (2014). Performance comparison of Islamic (participation) banks and commercial banks in Turkish banking sector. EuroMed Journal of Business, 9(2), 114-128.

Farooq, M., Van Wijnbergen, S., \& Zaheer, S. (2015). Will islamic banking make the world less risky? an empirical analysis of capital structure, risk shifting and financial stability.

Hasan, M., \& Dridi, J. (2011). The effects of the global crisis on Islamic and conventional banks: A comparative study. Journal of International Commerce, Economics and Policy, 2(2), 163-200.

Hassan, T., Mohamad, S., \& Khaled I. Bader, M. (2009). Efficiency of conventional versus islamic banks: evidence from the middle east. International Journal of Islamic and Middle Eastern Finance and Management, 2(1), 46-65.

Islamic banking bulletin march 2014 - the central bank. (2014). Retrieved May, 27, 2015, from http://www.sbp.org.pk/ibd/bulletin/2014/IBB-Mar-2014.pdf

Mohieldin, M. (2012). Realizing the potential of Islamic finance. Economic Premise(77), $1-7$.

Rosly, S., \& Bakar, M. (2003). Performance of Islamic and mainstream banks in Malaysia. International Journal of Social Economics, 30(12), 1249-1265.

Samad, A. (2004). Performance of interest-free islamic banks vis-à-vis interest-based conventional banks of bahrain. International Journal of Economics, Management and Accounting, 12(2), 27-36.

Samad, A., \& Hassan, M. K. (1999). The performance of Malaysian Islamic bank during 1984-1997: An exploratory study. International Journal of Islamic Financial Services, 1(3), 1-14.

Zaheer, S., Ongena, S., \& Van Wijnbergen, S. (2013). The transmission of monetary policy through conventional and islamic banks. European Banking Center Discussion Paper(2011-018), 2011-078. 


\section{Appendix}

Table A

\begin{tabular}{ll}
\hline \multicolumn{2}{l}{ Islamic Banks } \\
1. & Albaraka Bank \\
2. & BankIslami \\
3. & Burj Bank \\
4. & Dubai Islamic Bank \\
5. & Meezan Bank \\
\hline Conventional Banks \\
6. & National Bank \\
7. & Habib Bank \\
8. & MCB \\
9. & UBL \\
10. & Bank Al Habib \\
11. & Bank of Punjab \\
12. & NIB Bank \\
13. & Soneri Bank \\
14. & Habib Metro \\
15. & Allied Bank \\
16. & Summit Bank \\
17. & Samba Bank \\
18. & KASB Bank* \\
19. & JS Bank \\
20. & First Women Bank \\
\hline \multicolumn{2}{l}{ KASB Bank merged into Bank Islami in the year 2015}
\end{tabular}

